\title{
Investigations of dynamic characteristics of a tall industrial chimney due to light wind and solar radiation
}

\author{
Peter Breuer $^{1}$, Tadeusz Chmielewski ${ }^{2}$, Piotr Górski ${ }^{3}$, Eduard Konopka ${ }^{4}$, \\ Leslaw Tarczyński ${ }^{5}$ \\ ${ }^{1}$ Stuttgart University of Applied Sciences, Stuttgart, Germany,peter.breuer@hft.stuttgart.de \\ ${ }^{2}$ Opole University of Technology, Opole, Poland, t.chmielewski@po.opole.pl \\ ${ }^{3}$ Opole University of Technology, Opole, Poland,p.gorski@po.opole.pl \\ ${ }^{4}$ Stuttgart University of Applied Sciences, Stuttgart, Germany, eduard.konopka@hft.stuttgart.de \\ ${ }^{5}$ Opole University of Technology, Opole Poland, l.tarczynski@po.opole.pl
}

\begin{abstract}
The present paper describes field tests conducted on the $300 \mathrm{~m}$ tall industrial chimney, located in the power station of Bełchatów (Poland), where the GPS rover receivers were installed at three various levels. The objectives of these GPS tests were to investigate the deformed vertical profile of this chimney, and its dynamic characteristics, i.e. the first natural frequency and the modal damping ratios. The results for the satellite signal receptions, the synopsis of recorded baselines and their ambiguity solutions, drifts of the chimney due to solar radiation and air temperature variations and dynamic wind response characteristics are presented.
\end{abstract}

Keywords: chimney, monitoring, GPS, wind, temperature, dynamic, damping.

\section{Introduction}

The new area for measuring and monitoring of the total response to long-period engineering structures by using GPS technology has been developed within the last fifteen years $[1,2,3]$. The present paper describes two field tests conducted on the $300 \mathrm{~m}$ tall industrial chimney, located in the power station of Bełchatów (Poland), where the GPS rover receivers were installed at three various levels. To the authors' knowledge, this is the first temporal deployment of the GPS receivers in the world at different levels for dynamic monitoring of the tall structure due to the light wind and a combined influence of solar radiation and the daily air-temperature variations. The objectives of these two GPS tests were to investigate the deformed vertical profile of this chimney, and its dynamic characteristics, i.e. the first natural frequencies and the modal damping ratios. For these two objectives GPS positioning was provided for monitoring the horizontal displacement of the chimney at different levels above ground. The intervals for data recording (session lengths) had different lengths and were adapted for the aimed focus. For the first goal (the static deformation) a series of shorter sessions was previewed: every half an hour on all receivers the sessions lasted from 5 to 10 minutes simultaneously. Since the devices need some time for warming up, the effective recording time is shorter about one minute. For the second goal, especially for the modal damping ratios, a session lasting 2 hours was adequate. All GPS measurements were made with the sampling rate of $10 \mathrm{~Hz}$ by using four DualFrequency-Receivers: two receivers Leica GPS 500 and two receivers Leica GPS 1200. All data have been recorded on memory cards and processed later in the office.

\section{Monitoring the deflection of the chimney's vertical axis}

\subsection{Installation of GPS antennas}

Two comparable GPS tests for monitoring a vertical profile of the tall industrial chimney were carried out in December 2008 and in May 2011. The common characteristics 
were the simultaneous use of 4 GPS units recording with the data frequency of 10 Hertz and the installation of 3 rover antennas at the southern façade of the chimney at various levels above ground which are shown in Figs. 1 and 2.

a)

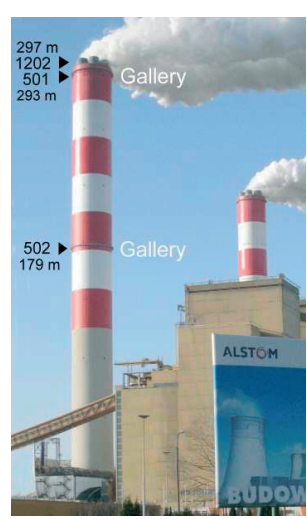

b)

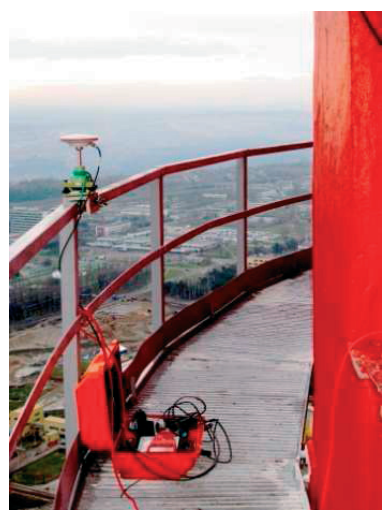

Fig. 1. East chimney in Bełchatów, 2008: (a) Installation of three rover antennas at various levels, (b) The antenna is fixed on the gallery handrail at a distance of $1 \mathrm{~m}$ from the wall

a)

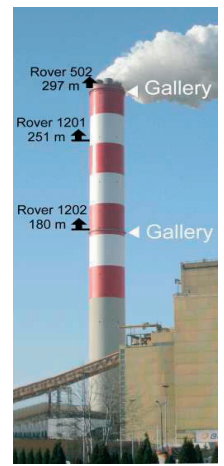

b)

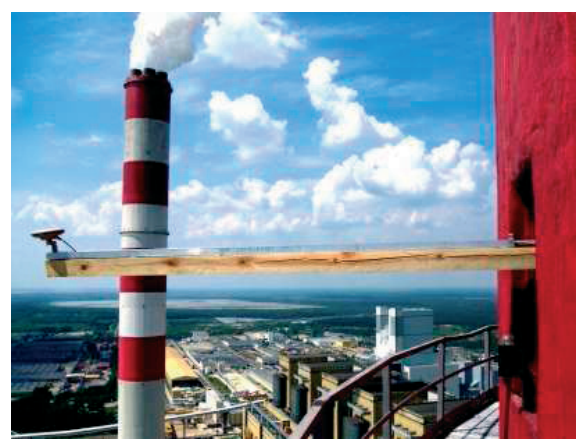

Fig. 2. East chimney in Bełchatów, 2011: (a) Installation of three rover antennas at various levels, (b) The antenna is fixedon a wooden cantilever a distance of $2.5 \mathrm{~m}$ from the wall

\subsection{The conditions for satellite signal reception}

GPS monitoring on the chimney's deck and particularly along the façade of the chimney suffers from the local obstacles which prevent the signal reception. Furthermore, during 24 hours the conditions for GPS positioning vary due to the changing number of available satellites and their geometrical configuration. Because of the shielding and the permanent change of satellite availability, some baselines could not be solved - as will be shown later on - neither in the static mode nor in the kinematic mode. In May 2011 the distance of the rover antennas at the interims heights has been extended towards the chimney wall from $1.0 \mathrm{~m}$ to $2.5 \mathrm{~m}$ by the use of overhanging cantilevers. Because of the larger distance from the wall the shadowing effect for the satellite signals is reduced in relation to December 2008.

\subsection{Observation intervals}

For the economical use of the available memory space the data recording was not processed continuously but at intervals. Every $30 \mathrm{~min}$ an observation interval was made for a period of several minutes. This period (the length of a session) had to be long enough for 
a successful baseline solution in the static as well as in the kinematic GPS mode. We know from experience that the session should last at least 3 minutes assuming the good GPS conditions. In December 2008 the rough length of a session was chosen to be 5 minutes, whereas in May 2011 it increased to 10 minutes.

\subsection{Meteorological conditions}

The meteorological data during both GPS tests were recorded locally on the chimney deck $(\mathrm{H}=297 \mathrm{~m})$. The data from the meteorological station Pabianice $(40 \mathrm{~km}$ north of Bełchatów) were available only in 2011. The data were used for the acquisition of the global radiation $\left(\mathrm{Watt} / \mathrm{m}^{2}\right.$ ). The local data were needed to detect the local strongest wind in order to evaluate the maximum response of the chimney during both GPS tests.

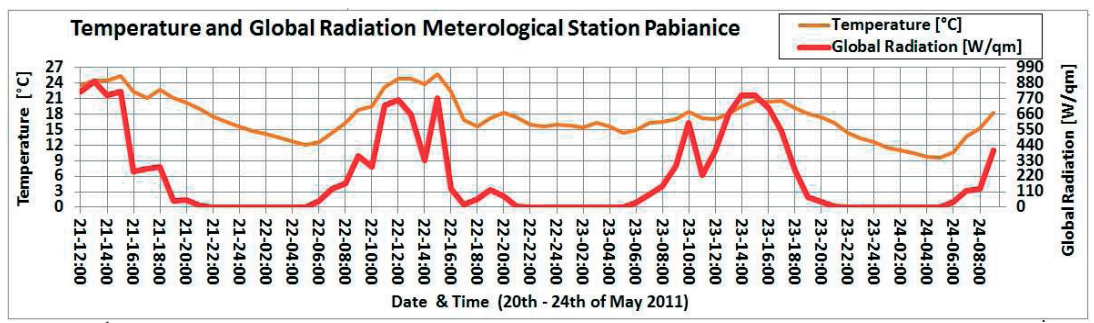

Fig. 3. $21^{\text {st }}-24^{\text {th }}$ of May 2011. Weather recording as concerns Pabianice (sun radiation and temperature

In December 2008, the changes in temperature during two-days of observations were low. Because of the minor temperature variations no significant displacement of the chimney was expected. The maximum wind velocity was about $21-27 \mathrm{~m} / \mathrm{sec}$ during the night from the $1^{\text {st }}$ to $2^{\text {nd }}$ of December 2008, while the wind azimuth was remarkably stable from the south-east.

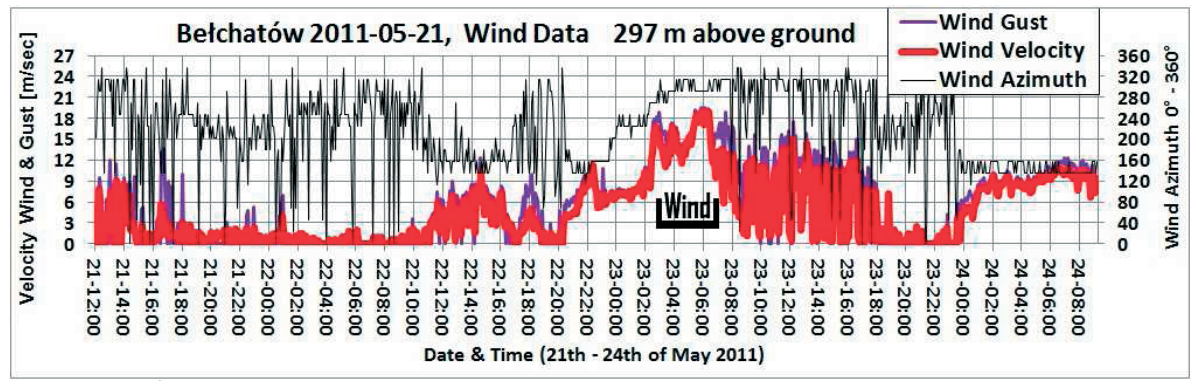

Fig. 4. $21^{\text {st }}-24^{\text {th }}$ of May 2011.Wind recording at the top of the chimney in Bełchatów

In May 2011 the global radiation (see Fig. 3) was only recorded in Pabianice, indicating strong radiation every day between 10 a.m. and 4 p.m., bringing about to a significant daily track (trail) in the west-east direction. During the test the maximum wind velocity of $12-19 \mathrm{~m} / \mathrm{sec}$ occurred only in the early morning of $23^{\text {th }}$ of May 2011 with a stable azimuth from the west.

\section{Results}

\subsection{Static component: drift due to solar radiation and air temperature variations at 3 levels}

For monitoring the sun-induced quasi-static response, the measurement were processed in the GPS static mode. Because of the minor temperature variation on the $1^{\text {st }}$ $3^{\text {rd }}$ of December 2008 no significant displacement of the chimney was expected. Daily course of displacement from the $21^{\text {st }}$ to $23^{\text {rd }}$ of May 2011 is documented in Figs. 5 and 6. 


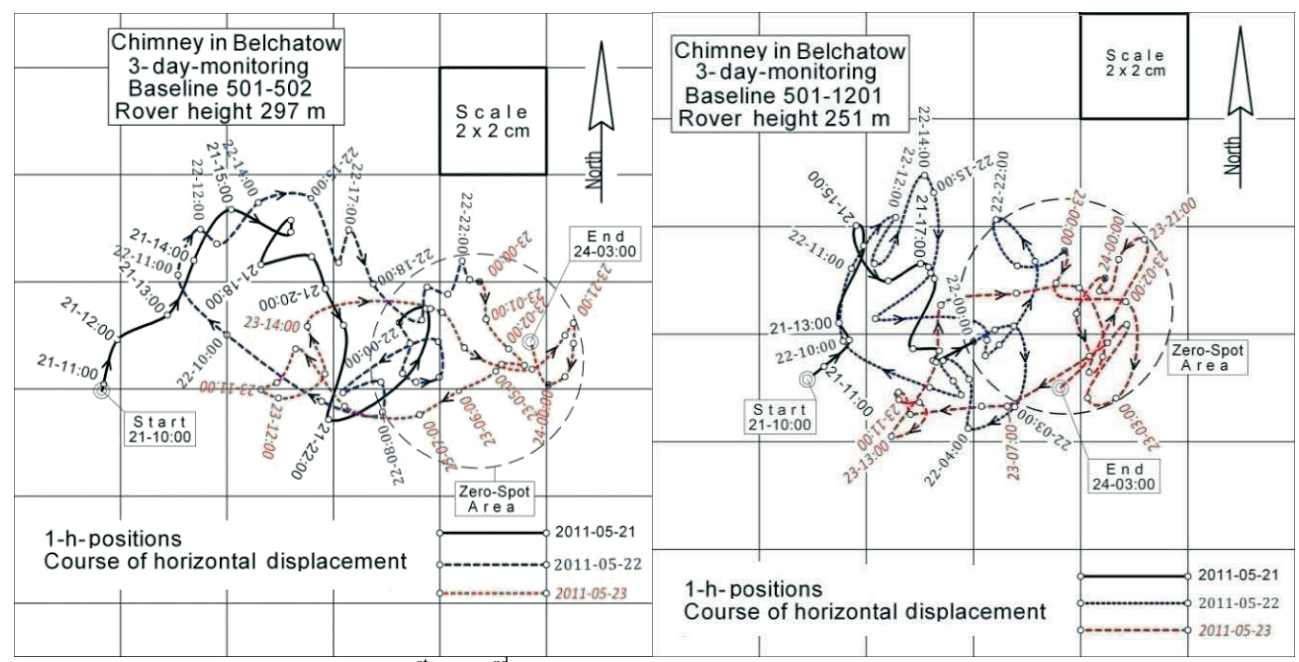

Fig. 5. Measurements from the $21^{\text {st }}$ to $23^{\text {rd }}$ of May. The course of horizontal displacement recorded by Rover $502(\mathrm{H}=297 \mathrm{~m})$ and Rover $1201(\mathrm{H}=251 \mathrm{~m})$

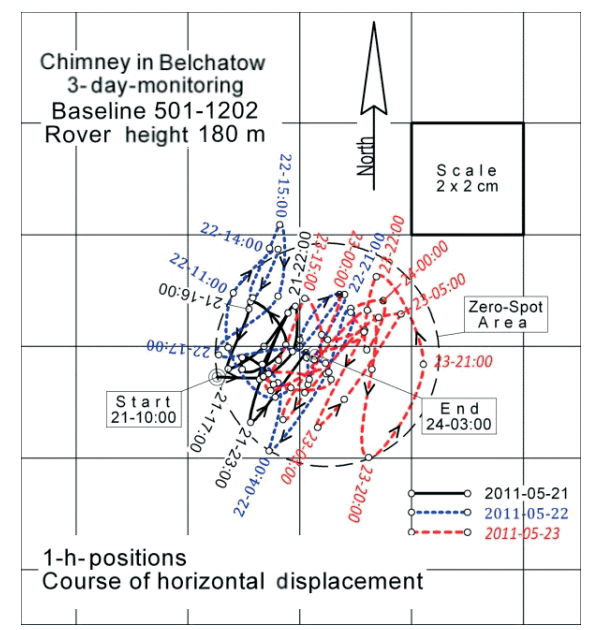

Fig. 6. Measurements from the $21^{\text {st }}$ to $23^{\text {rd }}$ of May. The course of the horizontal displacement during 3 days recorded by Rover 1202 (Height $\mathrm{H}=180 \mathrm{~m}$ ). A quasi-static component is not visible because of the absence of the strong wind

The west-east displacements of Rover $502(\mathrm{H}=297 \mathrm{~m})$ and Rover $1201(\mathrm{H}=251 \mathrm{~m})$ are highly correlated. In both graphs, the starting point of the course is situated in the southwest point outside the cluster. In the first hours the course of displacement leads to the northeast and reaches in each graph its northernmost point at the mark 21, 3 p.m. (21 ${ }^{\text {st }}$ May 2011, 3 p.m.). Then the deflection decreases and turns to the southeast towards the "zero spot area". In the morning of the second day starting at the time mark 22,8 a.m. (22 ${ }^{\text {nd }}$ May 2011, 8 a.m.) the course of displacement directs clearly to the west in both diagrams. In opposition to the test from December 2008 in the test from May 2011 (Figs. 13 and 14) no significant quasi-static component became visible. Whereas in December 2008 the wind velocity of up to $27 \mathrm{~m} / \mathrm{sec}$ occurred on the $1 \mathrm{st}$ of December, but in 2011 only a moderate wind velocity of $19 \mathrm{~m} / \mathrm{sec}$ occurred in the morning of the $23^{\text {rd }}$ of May 2011 between 3 a.m. and 7 a.m. This moderate wind velocity obviously made no quasi-static component visible. Probably the track of the temperature induced trail runs exactly opposite to the wind azimuth causing a superposition of both components. 


\subsection{The dynamic wind response characteristics in the vertical profile in May 2011}

During the test conducted in May 2011, data recording was done with a raw session length of $10 \mathrm{~min}$. Over a period of 65.5 hours the baseline observations were carried out simultaneously at all three rover stations (at the altitudes of $297 \mathrm{~m}, 251 \mathrm{~m}$ and $180 \mathrm{~m}$ above ground).

a)

b)
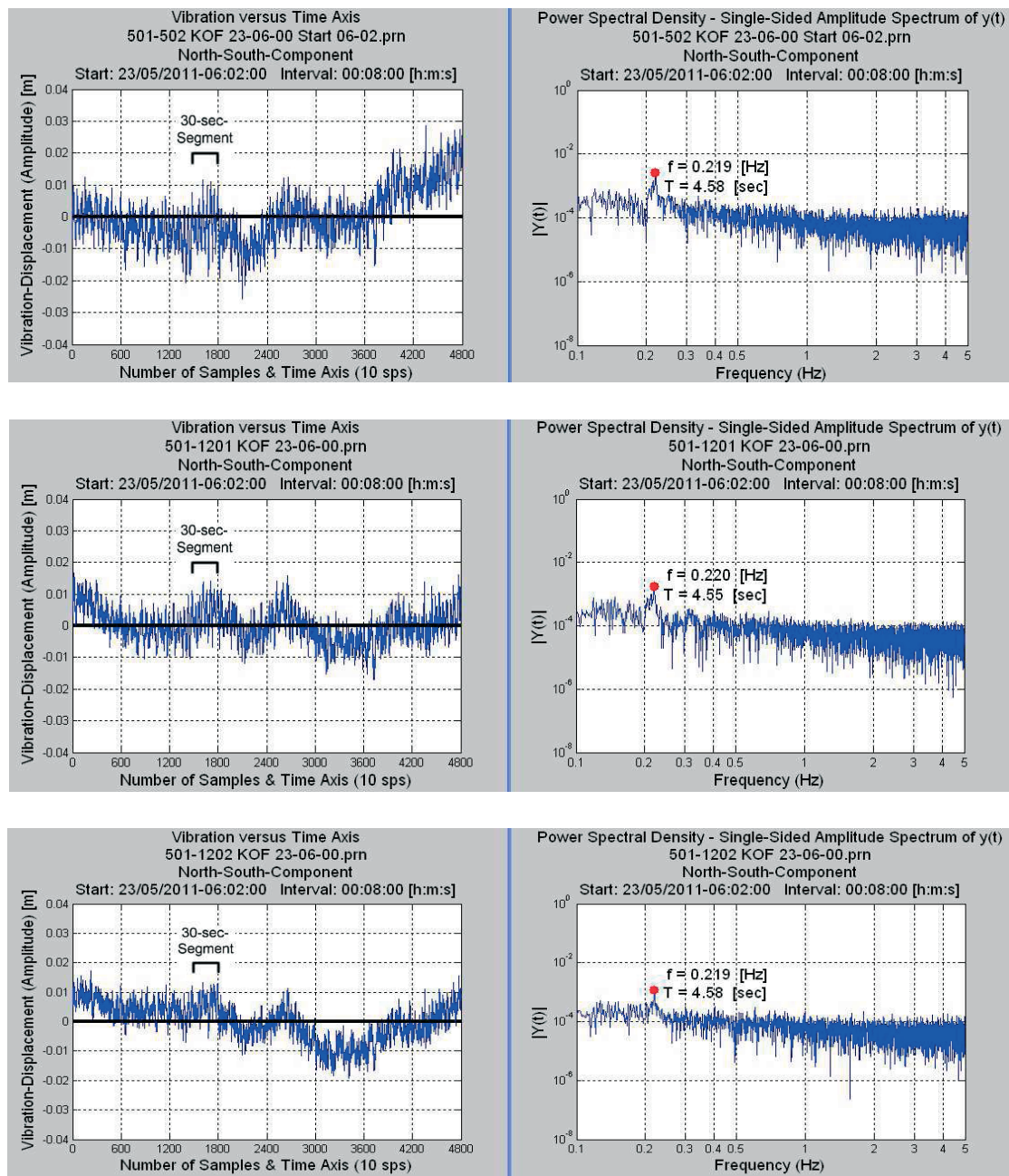

Fig.7. (a) Vibrations of the chimney at three levels: $\mathrm{H}=297 \mathrm{~m}, 251 \mathrm{~m}$ and $180 \mathrm{~m}$. during the west-north wind of $19 \mathrm{~m} / \mathrm{s}$ at the top of the chimney, north-south components over $8 \mathrm{~min}$ (4800 GPS positions), 7-8 satellites available, GDOP $=1.8-2.0$; (b) power spectral densities for these three records

The measurements were extended for such a long period to explain the effects of several different wind conditions. Of particular interest of course are periods of winds, which can be seen in Fig. 4. For example, a relative local maximum of the wind speed occurred on the $23^{\text {rd }}$ of May 2011 at 6 a.m. with the wind speed of up to $19 \mathrm{~m} / \mathrm{sec}$. Within this period, the wind is marked in Fig. 4. During the mentioned period of time the wind came from the west-northwest $\left(292.5^{\circ}\right)$ and was relatively stable. Fitting into this time (5.30 a.m., 6.00 a.m., 6.30 a.m.), in the static mode there were three simultaneously and 
successfully solved baselines.

Fig. 7a shows the three records of vibrations for each of the 3 GPS observation levels.A significant correlated trend can be observed for all three baselines as regards the systematic deviation from the zero axis. Furthermore, there is obviously the decreasing magnitude of the oscillation amplitude in correlation with the decreasing height above ground.

Fig. 7b shows the results of the Fast Fourier Transformation (frequency analysis) with clearly pronounced maxima. The calculated frequencies match all three baselines very well. There is only a frequency deviation of $0.001 \mathrm{Hertz}$ in the middle rover station $1201(\mathrm{H}=$ $251 \mathrm{~m})$ toward the two other stations. Comparing the assumed average value $(\mathrm{f}=0.219 \mathrm{~Hz})$ with the previous result $(\mathrm{f}=0.215 \mathrm{~Hz})$ of the first test in Section 7 there occurs a deviation of around $2 \%$ only.

\subsection{Synopsis of displacements related to the height}

During the test in May 2011, the rover antennas were installed on cantilevers at the interims levels and were pushed through the window openings at the south façade independent of the existing round-galleries. In that way the vertical distances between 3 levels in the vertical profiles could be selected in a more appropriate way than during the first test in December 2008. The vertical distance between the GPS-receiver on the chimney deck $(\mathrm{H}=297 \mathrm{~m})$ and the next rover were extended from a distance of $4 \mathrm{~m}(\mathrm{H}=293 \mathrm{~m})$ to a distance of $46 \mathrm{~m}(\mathrm{H}=251 \mathrm{~m})$. The ratio between a height of the rovers and the height of the chimney's deck becomes $100 \%, 84 \%$ and $60 \%$. This change in the ratio of the vertical distances gives more favorable conditions for assessing the bending line of the vertical chimney axis.

Table 1 gives a synopsis of the static, quasi-static and dynamic components of the displacements at 3 levels within the vertical GPS-profile. On the one hand, the table contains the linear displacements [mm] at each level; on the other hand, it shows the ratio between the actual displacement and the displacement at the top of the chimney.

The test from May 2011 provided more reliable results regarding the bending line of the vertical axis. The ratio of deflection in the Static Mode and in the Kinematic Mode almost matches between the rover stations 1201 and 1202. At rover station 1201 there is a good concordance with reference to the values of 0.71 and 0.78 . At rover station 1202 the concordance between the values of 0.41 and 0.39 is also excellent. The values from the theoretical deflection formula $(0.79$ and 0.48$)$ are about $10 \%$ higher with reference to the experimentally found values. This means that the deflection behavior of the chimney is not completely conform to the deflection of a homogeneous beam.

Table 1. May 2011. Table of horizontal displacements from the results of the static and kinematic GPS mode

\begin{tabular}{|c|c|c|c|c|c|c|}
\hline \multirow{2}{*}{$\begin{array}{l}\text { Displacements and properties in May } 2011 \\
\text { Y = measured horizontal displacement } \\
\text { Ratio = ratio of two horizontal displacements }\end{array}$} & \multicolumn{2}{|c|}{$\begin{array}{l}\text { Rover } 502 \\
\mathrm{H} 1=297 \mathrm{~m} \\
\mathrm{X}=297 / 297\end{array}$} & \multicolumn{2}{|c|}{$\begin{array}{l}\text { Rover } 1201 \\
\mathrm{H} 2=251 \mathrm{~m} \\
\mathrm{X}=251 / 297\end{array}$} & \multicolumn{2}{|c|}{$\begin{array}{l}\text { Rover } 1202 \\
\mathrm{H} 3=180 \mathrm{~m} \\
\mathrm{X}=180 / 297\end{array}$} \\
\hline & $\begin{array}{c}\mathrm{Y} 1 \\
{[\mathrm{~mm}]}\end{array}$ & $\begin{array}{c}\text { Ratio } \\
\mathrm{Y} 1 / \mathrm{Y} 1 \\
\end{array}$ & $\begin{array}{c}\mathrm{Y} 2 \\
{[\mathrm{~mm}]}\end{array}$ & $\begin{array}{c}\text { Ratio } \\
\mathrm{Y} 2 / \mathrm{Y} 1 \\
\end{array}$ & $\begin{array}{c}\mathrm{Y} 3 \\
{[\mathrm{~mm}]}\end{array}$ & $\begin{array}{c}\text { Ratio } \\
\mathrm{Y} 3 / \mathrm{Y} 1 \\
\end{array}$ \\
\hline $\begin{array}{l}\text { Static displacements due to global radiation: } \\
\text { Daily loop during } 85 \text { hours with the maximum } \\
\text { E-W-diameter of the daily loop. }\end{array}$ & 90 & 1.00 & 64 & 0.71 & 37 & 0.41 \\
\hline Quasi-static component & - & - & - & - & - & - \\
\hline $\begin{array}{l}\text { Dynamical deflection by wind load } \\
\text { north-south component during a } 30 \text {-second- } \\
\text { interval, magnitudes of the oscillation amplitude }\end{array}$ & 6.7 & 1.00 & 5.2 & 0.78 & 2.6 & 0.39 \\
\hline $\begin{array}{c}\text { Deflection of an ideal clamped beam: } \\
\mathrm{Y} \sim(\mathrm{x} 4 / 12-\mathrm{x} 3 / 3+\mathrm{x} 2 / 2) * 4 \\
\text { Deflection at the top } 100 \% \text {, at interim levels } \\
79 \%, 48 \%\end{array}$ & - & 1.00 & - & 0.79 & - & 0.48 \\
\hline
\end{tabular}




\section{Conclusions}

From our measurements we can draw the following conclusions:

The antenna installation along the vertical façade of the chimney brings about a partial loss of satellite signals and provides a signal reflection with the multi path effect During the test carried out in December 2008 the number of successfully resolved baselines was $31 \%(\mathrm{H}=179 \mathrm{~m}), 60 \%(\mathrm{H}=293 \mathrm{~m})$ and $91 \%(\mathrm{H}=297 \mathrm{~m})$, whereas during those conducted in May 2011 the number of successfully resolved baselines along the vertical profile increased to $83 \%(\mathrm{H}=180 \mathrm{~m})$ and $89 \%(\mathrm{H}=251 \mathrm{~m})$. At the chimney top they number decreased to $81 \%(\mathrm{H}=297 \mathrm{~m})$ probably because GPS1201 was changed by GPS500.

The quasi-static displacement of the chimney caused by the combined influence of solar radiation and daily air temperature variations resemble an ellipse for both tests. In December 2008 at the top of the chimney the greater diameter of this elliptical course was directed to the north and had a dimension of $4 \mathrm{~cm}$, disregarding the effect of static components of the wind action. In May 2011 the greater diameter of the daily path was orientated towards the west-east having a dimension of $9 \mathrm{~cm}$.

At the interim levels along the vertical profile at the south façade the following static components were monitored whereby the evaluated values were subsequently arranged from the upper to lower interim levels. During the test in December 2008, the maximum dimension of the daily elliptical course as it was recorded was $3 \mathrm{~cm}$ and $2 \mathrm{~cm}$ respectively. In May 2011, the maximum dimension of the daily path at the interims levels rose to $6 \mathrm{~cm}$ and $4 \mathrm{~cm}$ respectively, because of the larger displacements in the late spring.

The static component of wind action was monitored in December 2008 at local wind velocity of about $24 \mathrm{~m} / \mathrm{sec}$ at the top of the chimney. The horizontal displacement was registered about $2 \mathrm{~cm}$ at the chimney top. At the intermediate levels the recorded amplitudes were about $2 \mathrm{~cm}$ and $1 \mathrm{~cm}$ respectively. In May 2011, the maximum local wind velocity was about $19 \mathrm{~m} / \mathrm{sec}$ at the top of the chimney. During those winds, however no quasi-static displacement could be detected because of the superposition of this component with the azimuth of the temperature induced daily path.

In December 2008, when the wind velocity was $24 \mathrm{~m} / \mathrm{sec}$ and the crosswind vibration amplitude was about $7 \mathrm{~cm}, 7 \mathrm{~cm}$ and $3 \mathrm{~cm}$ was measured at the chimney top and at two observation levels respectively. In May 2012 only the maximum wind velocity was 19 $\mathrm{m} / \mathrm{sec}$ measured on the deck of the chimney. There also occurred oscillations in the northsouth-direction with the amplitudes of about $7 \mathrm{~mm}, 5 \mathrm{~mm}$ and $3 \mathrm{~mm}$.

During both tests only the first natural frequency of the chimney was detected by making use of the FFT method. In the first test (2008): $\mathrm{f}=0.215 \mathrm{~Hz}(\mathrm{~T}=4.65 \mathrm{~s})$, in the second (2011): $\mathrm{f}=0.219 \mathrm{~Hz}(\mathrm{~T}=4.57 \mathrm{~s})$.

The Random Decrement Method (RD) was used to determine the value of the damping ratio in the first mode of vibrations for which the natural frequency was detected. We obtained good results only during the first test by making use of the RD Method (for the north-component $\mathrm{f}_{1}=0.212 \mathrm{~Hz}, \xi_{1}=0.56 \%$ and $\mathrm{f}_{2}=0.219 \mathrm{~Hz}, \xi_{2}=0.82 \%$; for the east-component $\mathrm{f}_{1}=0.212 \mathrm{~Hz}, \xi_{1}=0.53 \%$ ).

During the second test the vibrations created by wind action were too small. Their accuracy in the GPS measurements was $\pm 5 \mathrm{~mm}$, it was impossible for us, however, to calculate damping since the conditions were not favorable for doing it.

\section{References}

1 Celebi M. GPS in dynamic monitoring of long-period structures. Soil Dynamics and Earthquake Engineering 20 (2000) 477-483.

2 Tamura Y, Matsui M, Pagnini Luisa-Carlotta, Ishibashi R, Yoshida A. Measurement of windinduced response of buildings using RTK-GPS. Journal of Wind Engineering and Industrial Aerodynamics 90 (2002) 1783-1793.

3 Breuer P, Chmielewski T, Górski P, Konopka E, Tarczynski L. The Stuttgart TV Tower displacement of the top caused by the effects of sun and wind. Engineering Structures 30 (2008) 2771-2781. 


\title{
Badania dynamicznych charakterystyk wysokiego komina pod działaniem słabego wiatru i nasłonecznienia
}

\author{
Peter Breuer ${ }^{1}$, Tadeusz Chmielewski ${ }^{2}$, Piotr Górski ${ }^{3}$, Eduard Konopka ${ }^{4}$, \\ Lesław Tarczyński ${ }^{5}$ \\ ${ }^{1}$ Stuttgart University of Applied Sciences, Stuttgart, Germany, peter.breuer@hft.stuttgart.de \\ ${ }^{2}$ Opole University of Technology, Opole, Poland, t.chmielewski@po.opole.pl \\ ${ }^{3}$ Opole University of Technology, Opole, Poland, p.gorski@po.opole.pl \\ ${ }^{4}$ Stuttgart University of Applied Sciences, Stuttgart, Germany, eduard.konopka@hft.stuttgart.de \\ ${ }^{5}$ Opole University of Technology, Opole Poland, l.tarczynski@po.opole.pl
}

Streszczenie: W ostatnich piętnastu latach powstała nowa dziedzina monitoringu dużych budowli inżynierskich wykorzystująca technologię GPS. W niniejszej pracy opisano badania przeprowadzone na wysokim, 300-metrowym kominie przemysłowym elektrowni Bełchatów, gdzie odbiorniki GPS umieszczono w trzech różnych poziomach. Według rozeznania autorów jest to pierwszy przypadek takiego użycia techniki GPS do obserwacji wysokiej budowli pod równoczesnym działaniem słabego wiatru oraz zmian temperatury otoczenia i nasłonecznienia. Celem badań było wyznaczenie geometrii odkształconej osi pionowej trzonu komina i jego parametrów dynamicznych, tj. pierwszej częstości drgań własnych i modalnych liczb tłumienia. Opisano warunki odbioru sygnałów satelitarnych systemu GPS, przedstawiono wyniki pomiarów przemieszczeń trzonu wywołanych nasłonecznieniem i wyniki analizy odpowiedzi dynamicznej konstrukcji komina wywołanej działaniem wiatru. tłumienie.

Słowa kluczowe: komin, monitoring, GPS, wiatr, nasłonecznienie, dynamika, 